\title{
Renal transplantation recipient patients survival
}

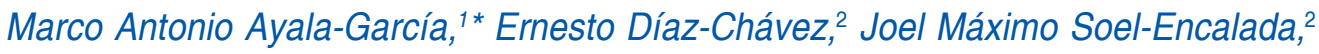 \\ Abel Orozco-Mosqueda, ${ }^{2}$ María Haydée Balandrán-Ortiz, ${ }^{3}$ Silvia Rebeca Ceja-Guzmán, ${ }^{4}$ \\ Saulit Garcidueñas-Garcidueñas, ${ }^{5}$ Gilberto Flores-Vargas ${ }^{6}$ and Eduardo Guaní-Guerra ${ }^{7}$ \\ ${ }^{1}$ Instituto Mexicano del Seguro Social, Hospital General Regional 58, Department of Surgery; ${ }^{2}$ Secretaría de Salud, Hospital Regional de Alta \\ Especialidad del Bajío, Transplant Unit; ${ }^{3}$ Secretaría de Salud del Estado de Guanajuato, Hospital General de Irapuato, Outpatient Department; \\ ${ }^{4}$ Secretaría de Salud del Estado de Guanajuato, Hospital General de Pénjamo, Department of Quality; ${ }^{5}$ Secretaría de Salud del Estado de \\ Guanajuato, Health Center with Extended Services, Department of Epidemiology; ${ }^{6}$ Centro de Investigaciones en Matemáticas A. C.; ${ }^{7}$ Secretaría \\ de Salud, Hospital Regional de Alta Especialidad del Bajío, Research Unit. Guanajuato, Mexico
}

\begin{abstract}
Introduction: The Bajío High Specialty Regional Hospital started operating in 2007 to tackle the health demands of 5.8 million inhabitants. It has 184 beds and a transplant unit with 26 beds. In 2008, the renal transplant program launched activities. Objective: To describe the survival of kidney transplant receptor patients and of the grafted kidney at the Bajío High Specialty Regional Hospital. Method: Retrospective cohort study, where consecutive transplants carried out between 2008 and 2016 were included. Statistical analysis was performed using the Kaplan-Meier method. Results: A total of 837 transplants were analyzed. Graft survival censored for death, with a functional graft at one and five years, was $94.6 \%$ and $78.9 \%$. Patient survival at one and five years was $95.4 \%$ and $88.1 \%$. Conclusions: The renal transplant program is one of the best programs established in Mexico, both for the number of deceased-donor kidney transplants performed and for the patient and graft survival achieved. These data indicate that the renal transplant program has had a sustained development.
\end{abstract}

KEY WORDS: Renal transplant. Patient survival. Graft survival.

\section{Supervivencia de los pacientes receptores de trasplante renal}

\section{Resumen}

Introducción: El Hospital Regional de Alta Especialidad del Bajío inició sus funciones en 2007 para atender la demanda de salud de 5.8 millones de habitantes, cuenta con 184 camas y una unidad de trasplantes con 26 camas. En 2008 inició actividades el programa de trasplante renal. Objetivo: Presentar la supervivencia de los pacientes receptores de trasplante renal y del riñón injertado en el Hospital Regional de Alta Especialidad del Bajío, Guanajuato, México. Método: Estudio de cohorte retrospectivo en el que se incluyeron los trasplantes consecutivos realizados entre 2008 y 2016. El análisis estadístico se efectuó con el método de Kaplan-Meier. Resultados: Se analizaron 837 trasplantes. La supervivencia del injerto censurada para muerte con injerto funcional a uno y cinco años fue de 94.6 y $78.9 \%$. La supervivencia del paciente a uno y cinco años fue de 95.4 y $88.1 \%$. Conclusiones: El programa de trasplante renal constituye uno de los mejor establecidos en México, tanto por el número de trasplantes renales de donante fallecido realizados como por la supervivencia obtenida de paciente einjerto. Los datos indican que el programa de trasplante renal ha tenido un desarrollo sostenido.

PALABRAS CLAVE: Trasplante Renal. Supervivencia paciente. Supervivencia injerto.

Correspondence:

*Marco Antonio Ayala-García

E-mail: drmarcoayala@ hotmail.com
Gac Med Mex. 2020;156:32-37

Contents available at PubMed

www.gacetamedicademexico.com

0016-3813/@ 2019 Academia Nacional de Medicina de México, A.C.. Published by Permanyer. This is an open access article under the CC BY-NC-ND license (http://creativecommons.org/licenses/by-nc-nd/4.0/). 


\section{Introduction}

Renal transplantation is the best treatment alternative for chronic end-stage renal disease. ${ }^{1}$ The first successful renal transplant in humans was carried out in 1954 (Boston, United States). In Mexico, the first renal transplant was performed on October 22, 1963 at the General Hospital of the National Medical Center of the Mexican Institute of Social Security. ${ }^{2}$ Currently, in Mexico there are 248 hospitals authorized to carry out kidney transplants; however, only 142 have this type of activity. ${ }^{3}$ In 2017, the Bajío Regional High Specialty Hospital (HRAEB - Hospital Regional de Alta Especialidad del Bajio) ranked fourth among the establishments with the largest number of transplants, with 129 procedures during that year, and ranked first in deceased-donor transplants. ${ }^{4}$ The national donation rate in 2016 was 32.2 per million population, with the rate of deceased-donor transplants being 15.5 per million population and the rate of brain-dead donor transplants 4.1 per million population. ${ }^{5}$ Over the last five years, an average of 2901 renal transplants were performed annually in Mexico, and there are 12477 patients waiting for a kidney. ${ }^{3}$

The HRAEB is a public institution and receives federal resources. It started operating in 2007 to address the health demands of approximately 5.8 million inhabitants of the states of Guanajuato, Jalisco, Michoacán, Aguascalientes and Zacatecas. It is a tertiary care hospital located in León, Guanajuato, in Central-Western Mexico, which has 184 beds, including 16 in the intensive care department, 15 in the emergency department and 26 in the transplant unit. In 2008, it started the kidney transplant program and, since 2014, it has a medical residency to train specialists in kidney transplantation surgery. ${ }^{6}$

This document analyses the survival of kidney transplant recipients and that of the grafted kidney, as well as relevant epidemiological information related to kidney transplant recipients at the HRAEB.

\section{Method}

Retrospective cohort study of 837 kidney transplants carried out from January 26, 2008 to December 31, 2016. The following variables were analyzed: age, gender, donor type, kidney disease etiology, immunosuppression, affiliation status, state of origin, mortality and graft loss. Measures of central tendency and dispersion (mean and standard deviation) were obtained for
Table 1. Characteristics of 837 patients who underwent kidney transplantation at the Bajío High Specialty Regional Hospital

\begin{tabular}{|c|c|c|}
\hline Variable & \multicolumn{2}{|c|}{ Mean \pm SD } \\
\hline Recipient age (years) & \multicolumn{2}{|c|}{$26.2 \pm 12.1$} \\
\hline & $\mathrm{n}$ & $\%$ \\
\hline Male recipient & 575 & 68.6 \\
\hline Deceased donor & 409 & 48.8 \\
\hline Related living donor & 385 & 45.9 \\
\hline Unrelated living donor & 43 & 5.1 \\
\hline $\begin{array}{l}\text { Renal disease etiology } \\
\text { Unknown } \\
\text { Secondary glomerulopathy } \\
\text { Primary glomerulopathy } \\
\text { Nephropathy due to urinary tract malformation } \\
\text { Polycystic disease } \\
\text { Congenital glomerulopathy }\end{array}$ & $\begin{array}{l}631 \\
106 \\
57 \\
20 \\
20 \\
3\end{array}$ & $\begin{array}{l}75.3 \\
12.6 \\
6.8 \\
2.3 \\
2.3 \\
0.3\end{array}$ \\
\hline $\begin{array}{l}\text { Immunosuppression } \\
\text { Induction with basiliximab } \\
\text { Induction with thymoglobulin } \\
\text { Induction with daclizumab } \\
\text { No induction } \\
\text { Cyclosporine-mycophenolate mofetil-prednisone } \\
\text { Tacrolimus-mycophenolate mofetil-prednisone } \\
\text { No immunosuppression due to patient death }\end{array}$ & $\begin{array}{c}492 \\
92 \\
5 \\
248 \\
542 \\
290 \\
5\end{array}$ & $\begin{array}{c}58.7 \\
10.9 \\
0.5 \\
29.6 \\
64.7 \\
34.6 \\
0.5\end{array}$ \\
\hline $\begin{array}{l}\text { Affiliation status } \\
\text { No social security } \\
\text { Mexican Institute of Social Security } \\
\text { Institute of Social Security and Services for State } \\
\text { Workers } \\
\text { National Ministry of Defense }\end{array}$ & $\begin{array}{c}511 \\
315 \\
10 \\
1\end{array}$ & $\begin{array}{c}61 \\
37.6 \\
1.1 \\
0.1\end{array}$ \\
\hline $\begin{array}{l}\text { State of origin } \\
\text { Guanajuato } \\
\text { Jalisco } \\
\text { Zacatecas } \\
\text { Michoacán } \\
\text { San Luis Potosí } \\
\text { Querétaro } \\
\text { Distrito Federal }\end{array}$ & $\begin{array}{l}789 \\
21 \\
15 \\
7 \\
2 \\
2 \\
1\end{array}$ & $\begin{array}{l}94.2 \\
2.5 \\
1.7 \\
0.8 \\
0.2 \\
0.2 \\
0.1\end{array}$ \\
\hline
\end{tabular}

quantitative variables and proportions for qualitative variables. Survival analysis was carried out with the Kaplan-Meier method. Patient and graft survival censored for death with a functional graft is shown. To establish the differences in survival according to the type of donor, the log-rank test was used; the level of significance was established at $p<0.05$. All information came from the HRAEB Transplant Unit database and from each patient's electronic medical record and physical file.

\section{Results}

Data from the first nine years of the HRAEB kidney transplant program were analyzed, i.e., 837 renal 


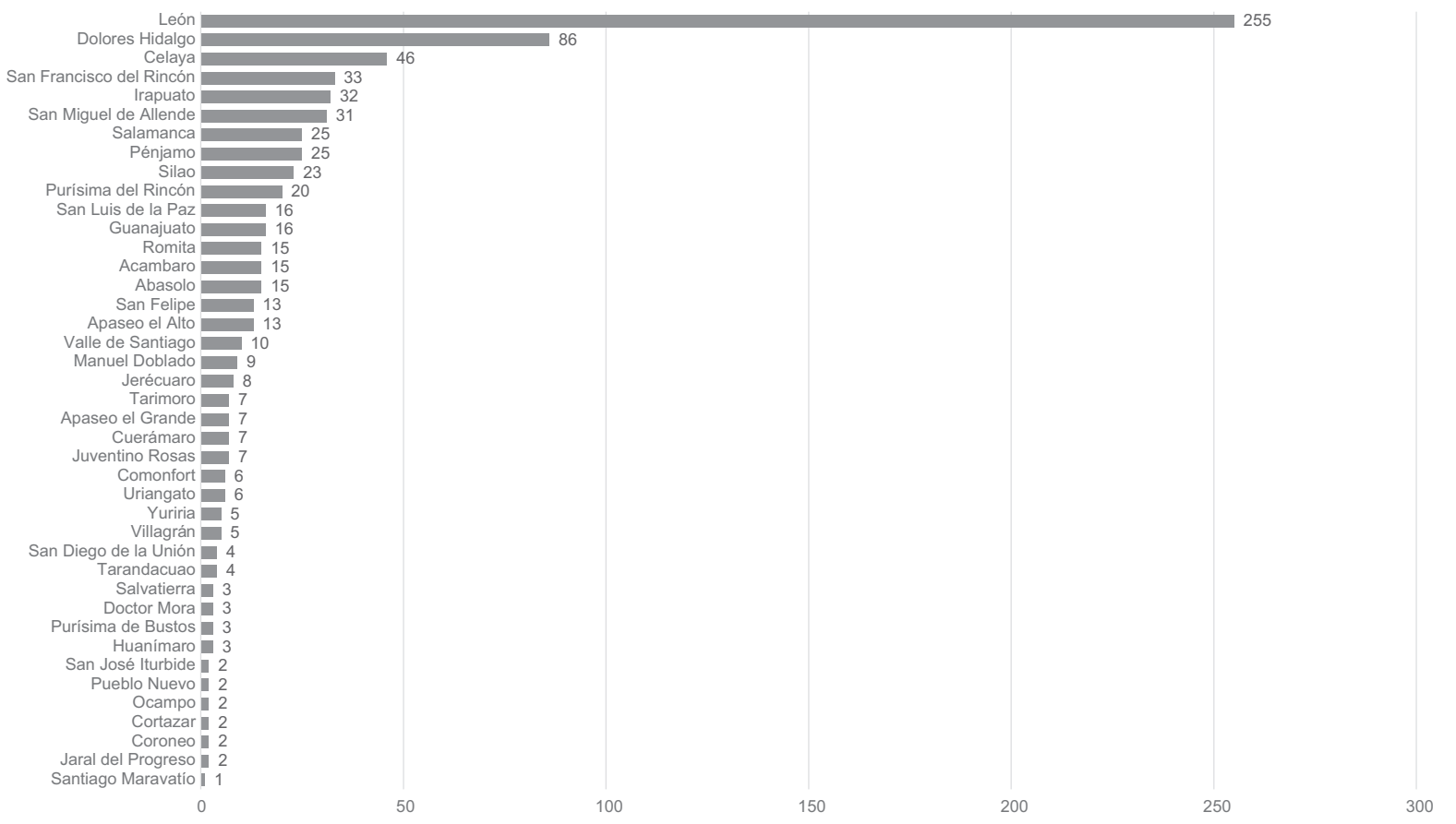

Figure 1. Guanajuato State municipality of origin of patients undergoing kidney transplantation at the Bajío Regional High Specialty Hospital $(n=789)$

Table 2. Causes of death in 69 patients with kidney transplantation

\begin{tabular}{|l|c|c|}
\hline Cause & n & $\%$ \\
\hline End-stage renal disease (graft failure) & 26 & 37.6 \\
\hline Acute graft rejection & 14 & 20.2 \\
\hline Graft-related chronic kidney disease & 6 & 8.6 \\
\hline Unknown & 3 & 4.3 \\
\hline Infection and subsequent graft removal & 2 & 2.9 \\
\hline Graft primary dysfunction & 1 & 1.4 \\
\hline Infectious & 26 & 37.6 \\
\hline Neoplasms & 7 & 10.1 \\
\hline Non-infectious lung disease & 2 & 2.8 \\
\hline Acute myocardial infarction & 2 & 2.8 \\
\hline Hemorrhage & 2 & 2.8 \\
\hline Suicide & 2 & 2.8 \\
\hline Diabetes mellitus complications & 1 & 1.4 \\
\hline Homicide & 1 & 1.4 \\
\hline
\end{tabular}

transplantations carried out between January 26, 2008 and December 31, 2016. Of the kidney transplant recipient patients, only four received a second renal graft. Four-hundred and nine $(48.8 \%)$ deceased donor and $428(51.1 \%)$ living donor transplants were performed. Renal transplant recipients mean age \pm standard deviation was $26.2 \pm 12.1$ years, with a range of 3 to 69 .

As for deceased donors, mean age was $28.6 \pm$ 15 years, with a range of 0 to 65 . Regarding living donors, 385 were related and 43 unrelated, and their mean age was $36.4 \pm 10.3$ years, with a range of 18 to 54 . When donor ages were compared, a significant difference $(p<0.001)$ was found between the deceased and the living donors.

Renal failure etiology was unknown in 631 recipients $(75.3 \%)$. Immunosuppression induction was used in 589 patients $70.4 \%$. The most commonly used immunosuppression scheme was that of cyclosporine. Among the kidney transplant recipients, $511(61 \%)$ had no social security (Table 1) and $94.2 \%$ were natives to the state of Guanajuato; the municipality of origin is indicated in Figure 1.

A mortality rate of $8.2 \%$ was recorded (69 deaths among 837 transplanted subjects); the causes of death are described in Table 2. One-hundred and eleven grafts were lost (13.2\% of those transplanted).

Graft survival censored for death with a functional graft at one, three, five and eight years was 94.6, 88.6, 78.9 and $69.4 \%$. Figure 2 shows the Kaplan-Meier curves for graft survival censored for death with a functional graft according to the type of donor. The log-rank test was used to compare both groups for graft survival according to the type of donor at nine 


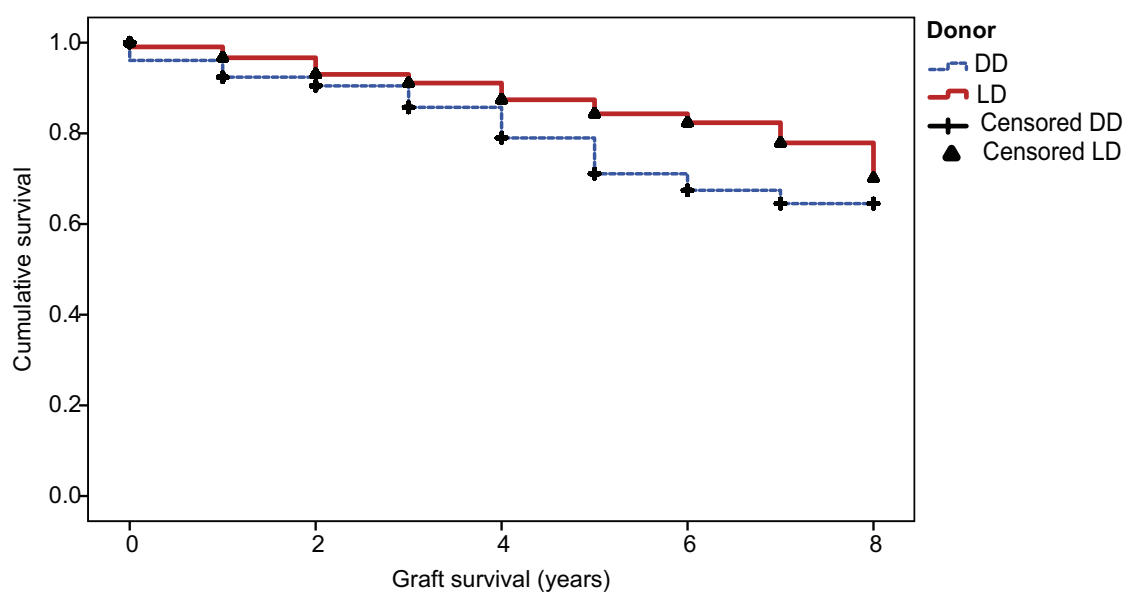

Figure 2. Kaplan-Meier curves for the survival of kidney grafts transplanted at the Bajío Regional High Specialty Hospital. LD = living donor, $D D=$ deceased donor.

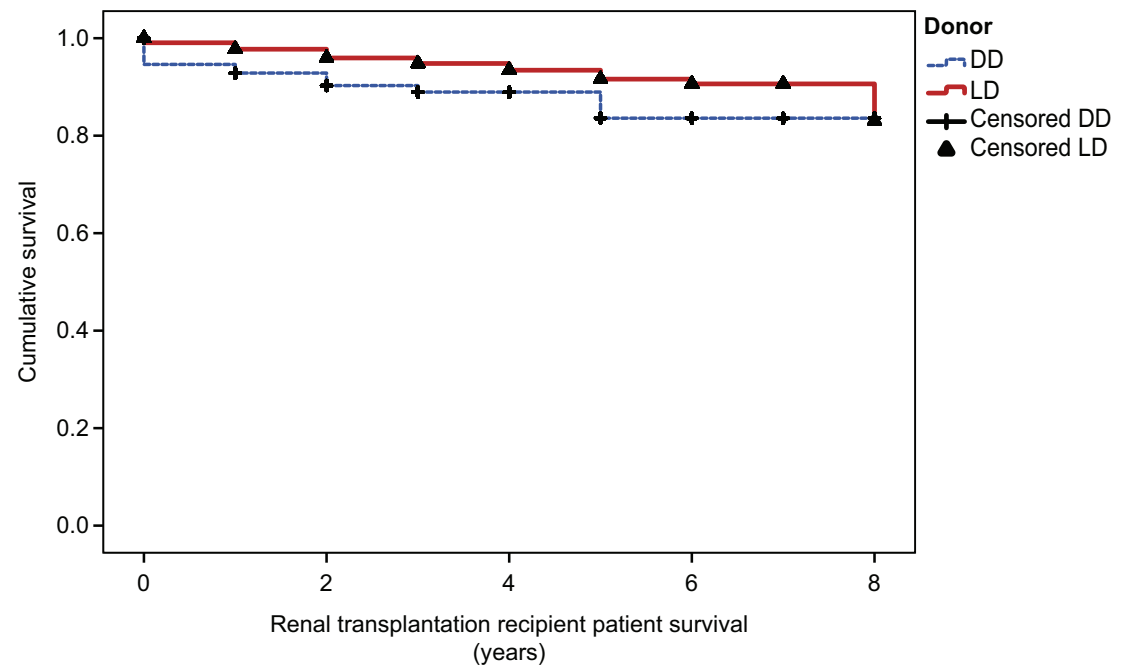

Figure 3. Kaplan-Meier curves for the survival of patients receiving a kidney transplant at the Bajio Regional High Specialty Hospital. LD = living donor, $D D=$ deceased donor.

years, with a statistically significant difference being found $(p=0.002)$.

Kidney transplant recipient patients censored survival at one, three, five and eight years was 95.4, 92, 88.1 and $84.4 \%$, respectively. Figure 3 shows the Kaplan-Meier curves for renal transplant recipient patients' survival according to the type of donor. The log-rank test was used to compare nine-year recipient survival in both groups according to the type of donor, whereby a statistically significant difference was found $(p=0.003)$.

\section{Discussion}

The results of the first nine years of the HRAEB kidney transplant program are presented. In 2016,
$3.2 \%$ of renal transplants performed in Mexico (98 out of 2970 procedures) and $6.7 \%$ of deceased donor kidney transplants (57 out of 844 performed in the country) were carried out at the HRAEB, whereby it was ranked first in Mexico among the establishments with higher deceased-donor renal transplantation activity. ${ }^{5}$

The number of kidney transplants carried out in similar hospitals in Mexico, such as the National Institute of Medical Sciences and Nutrition "Salvador Zubirán", which in 44 years (1967-2011) performed 1000 kidney transplants, ${ }^{7}$ and the Veracruz Regional High Specialty Hospital, which in a period of 10 years (2006-2016) carried out 95 kidney transplantations, ${ }^{8}$ is in contrast with the 837 procedures practiced in nine years (2008-2016) at HRAEB, which makes it one 
of the most important hospitals in Mexico with regard to this procedure.

The HRAEB is a regional hospital, i.e., it has to cover the demands of the Guanajuato, Jalisco, Michoacán, Aguascalientes and Zacatecas populations. However, $94.2 \%$ of patients who receive kidney transplants are from Guanajuato and $30.4 \%$, i.e., 255 of the recipients from the Guanajuato state belong to the municipality of León, which is explained by the location of this hospital in León.

Patients from 41 of the 46 municipalities of the state of Guanajuato have been included in the HRAEB transplant program, but there are no patients from Atarjea, Tierra Blanca, Xichú, Santa Catarina and Victoria, which are municipalities located northeast of the Guanajuato state, far away from the HRAEB, which may be one of the reasons why patients of these municipalities are not referred, do not attend the HRAEB, and are treated in other hospitals such as the "Dr. Ignacio Morones Prieto" Central Hospital, in San Luis Potosí (if they are affiliated to the Mexican Institute of Social Security) or the Querétaro Regional Hospital 1.

Patients receiving renal transplantation at HRAEB were young adults with an average age of 26.2 years, similar to that reported at the National Institute of Medical Sciences and Nutrition "Salvador Zubirán" (31.7 \pm 11.3 years), ${ }^{7}$ at Veracruz Regional High Specialty Hospital $\left(31.4 \pm 12.8\right.$ years), ${ }^{8}$ at National Cardiology Institute "Ignacio Chávez" (29.9 \pm 11.6 years), ${ }^{9}$ at "Bernardo Sepúlveda" Specialty Hospital of the National Medical Center Siglo XXI (31.4 \pm 10.5 years), ${ }^{1}$ at Hospital Miguel Hidalgo in Aguascalientes $\left(29.3 \pm 15\right.$ years), ${ }^{10}$ at "Dr. Ignacio Morones Prieto" Central Hospital (26.8 \pm 16.6 years) $)^{11}$ and at the Mexican Institute of Transplants $\left(31 \pm 10\right.$ years). ${ }^{12}$

The etiology of end-stage renal disease was unknown in $75.3 \%$ of cases, since HRAEB is a reference hospital and the majority of transplanted patients were at late stages of the disease, and renal biopsy for diagnostic purposes was therefore no longer an option. To avoid this, it is necessary for early detection programs to be implemented at primary care hospitals and health centers.

During the reported period, only two immunosuppression schemes were used at HRAEB: cyclosporine-mycophenolate mofetil-prednisone and tacrolimus-mycophenolate mofetil-prednisone.

Comparisons with data reported in the literature regarding kidney transplant recipients and graft survival in Mexico are limited due to the variability in the methodology of analysis and data handling, as well as for the fact that cohorts with different periods were analyzed; ${ }^{1,7-12}$ however, we can point out that there are differences $(p>0.05)$ regarding the survival of patients with renal transplantation reported in Spain: 91, 81 and $57 \%$ at one, two and three years respectively, ${ }^{13}$ in contrast to the survival rates found in this study: 95.4, 93.2 and $92 \%$, for the same periods.

In this study, survival of the living-donor kidney transplantation recipient, both of the patient and the graft, was higher in comparison with that of the deceased-donor renal transplant recipient, as noted in other investigations. ${ }^{1,7-12}$ According to different analyses, there are several factors that might contribute to explain the better survival and glomerular filtration of living-donor transplants, ${ }^{14-16}$ such as blood group typing and histocompatibility tests that are routinely practiced at HRAEB:

- Donor and recipient HLA typing through molecular biology with sequence-specific primer (SSP)type polymerase chain reaction for classes I and II (A, B, DRB1 and DQB1).

- Anti-HLA alloantibodies through the antibody reactive panel with the ELISA methodology (solid phase).

- Lymphocyte crossmatch assay for complement-mediated cytotoxicity, with the use of total lymphocytes and dithiothreitol.

Regarding living donors, we did not have the HLA compatibility data of $5.1 \%(22 / 428)$ of donor-recipient dyads, $64.5 \%(276 / 428)$ did match in one donor-recipient haplotype and $9.1 \%$ (39/428) did match in two donor-recipient haplotypes; therefore HLA identity (matching of one and two haplotypes) contributed for $73.6 \%(297 / 428)$ of living-donor kidney transplant recipients to have a better survival than deceased-donor kidney transplant recipients.

\section{Conclusions}

The HRAEB renal transplant program is one of the more robust programs in Mexico, both for the number of deceased-donor kidney transplants performed and for the patient and graft survival obtained. Despite being a relatively recent program (nine years) in a hospital with barely 10 years of existence, recipient and graft survival is better than in other hospitals with more experience in the procedure. Our data also indicate that the renal transplant program has had a sustained development. 


\section{References}

1. Gracida-Juárez C, Espinoza-Pérez R, Cancino-López JD, Ibarra-Villanueva A, Cedillo-López U, Villegas-Anzo F, et al. Kidney transplant experience at the Specialty Hospital Bernardo Sepúlveda National Medical Center Century XXI, Mexican Institute of Social Security. Rev Invest Clin. 2011;63:19-24.

2. Quijano M, Gomez-Mont F, Ortiz-Quezada, Ronces R. First experiences in human renal transplantation. Gac Med Mex. 1964;94:93-105

3. Aburto S. Behavior of the donation and procurement of organs and tissues; receptors waiting for transplant; authorized units for procurement of transplants. Bol Estad Inform. 2016;1:15-42.

4. Centro Nacional de Trasplantes. Estadísticas [en línea]. México: Centro Nacional de Trasplantes; 2018.

5. Aburto S. Results 2015-2016, balance to two years of management in CENATRA. Bol Estad Inform. 2016;1:12-14.

6. Díaz-Chávez E, Orozco-Mosqueda A, Soel-Encalada J, Alemán-Suárez, D, Pérez-Granados, Gontes-Godínez J, et al. Initial report on the Results of the Kidney Transplant Program at the Bajio Regional High Specialty Hospital. Transplant Proc. 2016;48:620-624.

7. Marino-Vázquez LA, Sánchez-Ugarte R, Morales-Buenrostro LE. Kidney transplantation: consecutive one thousand transplants at National Institute of Medical Sciences and Nutrition Salvador Zubirán in México City. Rev Invest Clin. 2011;63:6-13.

8. Martínez-Mier G, Ávila-Pardo S, Irigoyen-Castillo A, Rodríguez-Fernán$\operatorname{dez} A$, Jiménez-López L, Varela-Pérez V. Analysis of the survival to 10 years of kidney transplant in the Hospital of High Specialty of Veracruz. Rev Mex Trasplant. 2016:5:113-119.
9. Mancilla-Urrea E, Aburto-Morales S, Kasep-Bahena J, Rodríguez-Castellanos F. Kidney transplant program at the Instituto Nacional de Cardiología Ignacio Chávez. Rev Invest Clin. 2011;63:14-18.

10. Reyes-Acevedo R, Romo-Franco L, Delgadillo-Castañeda R, Orozco-Lozano I, Melchor-Romo M, Gil-Guzmán E, et al. Renal transplantation program at the Centenario Hospital Miguel Hidalgo in Aguascalientes, México. Rev Invest Clin 2011;63:30-37.

11. González-Audiffred N, Alfaro-Abúndiz F, Aranda-Verástegui F, Isordia-Segovia J, Chevaille-Ramos A, Montes-De Oca-Arce J, et al. Experience in kidney transplantation from 1999 to 2011 at the Hospital Central Dr. Ignacio Morones Prieto, San Luis Potosi. Rev Invest Clin. 2011; 63:38-43.

12. Mondragón-Ramírez G, Bochicchio-Riccardelli T, Bernal-Flores L, León-Rojas G, Martínez-Hernández J, Orozco-Tapia L, et al. Kidney transplant program: Mexican Institute of Transplants. Model of synergy between private hospital and private assistance foundations. Rev Invest Clin. 2011;63:44-49.

13. Martín-Escobar E. The Spanish Renal Registry: 2013 report and evolution from 2007 to 2013. Nefrologia. 2016;36:97-120.

14. Guirado L, Vela-Vallespín E, Clèries M, Díaz J, Facundo C, García-Maseta R. Why living-donor renal transplant yields better outcomes than cadaver renal transplant? Nefrologia. 2008;28:159-167.

15. Valdivia J, Gutiérrez C, Delgado E, Daymiris F, Treto J, Fernández I. Survival in kidney transplant with living donor transplant and cadaver donor. Investigaciones Medicoquirúrgicas. 2011;3:102-110.

16. Castañeda D, López L, Martín I, Martín R, Lozano E. Living kidney donors and kidney transplantation: a general overview. Urol Colomb. 2014;23:205-213. 